\title{
THE CONNECTION OF EU SUPPORTS AND THE TAXABLE INCOME PER CAPITA IN THE NORTHERN HUNGARIAN REGION, FOR THE 2007-2013 PERIOD
}

\section{EU TÁMOGATÁSOK ÉS JÖVEDELMEK KAPCSOLATA A 2007-2013- AS IDŐSZAKBAN, AZ ÉSZAK-MAGYARORSZÁGI RÉGIÓBAN}

\author{
Dóra SZENDI ${ }^{\mathrm{a}}$ \\ ${ }^{a}$ University of Miskolc, Faculty of Economics, Institute of World and Regional Economics, 3515 \\ Miskolc-Egyetemváros, regszdor@uni-miskolc.hu
}

Cite this article: Szendi, D. (2017) The Connection of EU Supports and the Taxable Income Per Capita in the Northern Hungarian Region, for the 2007-2013 Period. Deturope. 9(3):42-60

\begin{abstract}
The territorial social and economic inequality is one of the most fundamental characteristics of space economics. There are not two points in the space which have the same characteristics, because their economic, social and cultural parameters are different. The existence of territorial inequalities is a significant problem also in the case of Hungary with special regards on the settlements of the Northern Hungarian region. The aim of my research is to examine the spatial patterns of the EU supports and the income per employee in the case of the Northern Hungarian region's settlements and to analyze what kind of effect the supports have on the dispersion of the settlements' income. According to the results, I can state that there are more hot spots in the region based on the EU supports, than by the income per capita, so the pattern is more heterogeneous. Consequently, there is observable a greater gap among the settlements based on the supports by the inequality measures. The Local Moran clusters forming through the analysis of EU supports and income per employee show significant similarity, $93.48 \%$ of the small- and medium-sized cities, and $96.16 \%$ of the settlements of the most disadvantaged areas can be grouped into the same cluster according to both indicators.
\end{abstract}

Keywords: territorial inequalities, Northern Hungarian region, income, EU supports.

\begin{abstract}
Absztrakt
A területi szintű társadalmi, gazdasági egyenlőtlenség a térgazdaságtan egyik alapvető jellemzője. Nincs a térnek két olyan pontja, mely azonos tulajdonságokkal rendelkezne, mert a gazdasági, társadalmi, és kulturális paramétereik különbözőek. A területi egyenlötlenségek fennállása komoly probléma Magyarország esetében is, különös tekintettel az Észak-magyarországi régió településeire. Tanulmányom célja az Észak-magyarországi régió települései körében annak vizsgálata, hogy az EU támogatásainak és az egy fóállású foglalkoztatottra jutó jövedelmek eloszlásában milyen térbeli mintázatok azonosíthatók, illetve hogy a támogatások milyen hatást fejtenek ki a települések jövedelmi helyzetére. Az eredmények alapján elmondható, hogy a régió településeinek körében az uniós támogatások eloszlása heterogénebb képet mutat, mint a jövedelemé, ugyanis esetében több kiugró érték definiálható. Következésképpen, az EU támogatások eloszlása jelentősebb differenciákat mutat az egyenlötlenségi mérőszámok alapján is. Az egy föállású foglalkoztatottra jövedelmek és az egy före jutó EU támogatások eloszlásában a kialakuló Local Moran klaszterek jelentős hasonlóságot mutatnak, a kis és középvárosok az esetek 93,48\%-ában, míg az LHH térségek települései az esetek 96,16\%-ában mindkét mutató alapján ugyanabba a csoportba sorolhatók.
\end{abstract}

Kulcsszavak: területi egyenlőtlenségek, Észak-magyarországi régió, jövedelmek, EU támogatások. 


\section{INTRODUCTION}

The territorial social and economic inequality is one of the most fundamental factors of space economics (Nemes Nagy, 1990; Nagyné Molnár, 2007). There are not two points in the space which have the same characteristics, because their economic, social and cultural parameters are different (Nagyné Molnár, 2007; Benedek-Kurkó, 2011). The scale of difference can vary in time and space. According to some researchers' opinion, there are two special positions in the space: the centre and the periphery (Nemes Nagy, 2005). Most of the peripheral regions are not only based on some economic indicators (like GDP or the number of enterprises) disadvantaged, but also in the quality of life and migration. That is why the decrease of the territorial inequalities and the catch up of peripheries is an important issue for the economic policy.

The analysis of spatial inequalities has high priority also in the European Union. The reason: with the increasing number of EU member countries the economic and social disparities were also increasing. The EU examines the territorial inequalities since almost more than 20 years. According to the latest dates of the Eurostat (2016), there is a 54-fold difference between the richest Inner London and the poorest Severozapaden (Bulgaria) region (in purchasing power-parity 20-fold) in terms of GDP per capita. The difference was in 2000 between the richest Inner London and poorest Extremadura (Spain) region only 13-fold (in purchasing power-parity 8.25 -fold).

The territorial inequalities are current also in Hungary, where the Northern Hungarian region is in one of the worst situation among the regions based on some economic and social indicators (e.g., $7^{\text {th }}$, last place in GDP/capita ranking; $6^{\text {th }}$ in unemployment rate; $6^{\text {th }}$ in research and development expenditures; and $6^{\text {th }}$ in the income of households in 2015). In this recent research, I will analyze the spatial patterns of the EU supports and the income per employee in the case of the Northern Hungarian region's settlements. The aim of the research is to examine what kind of intraregional disparities can be verified in the region (which patterns can be identified among the settlements) and whether the role of space is a significant factor in the distribution of dates. Through the analysis, I have defined two specific settlement categories on which I have made a deeper focus, as I thought these could be the extreme points of the analysis. These areas are the region's small- and medium-sized cities and the settlements of the most disadvantaged areas which need a complex development program. 
Szendi, D.

\section{THEORETICAL BACKGROUND AND EMPIRICAL EXPERIENCES}

\section{Theories of convergence and the role of space}

The analysis of territorial inequalities is not new; several researchers have examined the positive convergence chances of the peripheries (e.g., nation states convergence process by Barro and Sala-i-Martin, 1992; Mankiw et al., 1992; Romer, 1994; Sala-i-Martin, 1995; Quah, 1996). The empirical analysis of convergence dates back to the 1960s. In that time the neoclassical growth theories (such as Solow) were in the foreground of the analyses. In these theories the territorial inequalities are disappearing in the long run, hence the income levels of the poorest economies will be converging to the richer ones because they tend to have higher growth rates than the richer ones (Barro, 1991, p. 407). From the 1930s, besides the neoclassical school, there was another school existing parallel, which is named after Keynes. The Keynesian models' main aim is on understanding divergence. According to their assumptions there is not an initial condition beside which the flow of factors brings the economy to equilibrium. The differences in the regions' growth rates will be not decreasing in the long run, but they will increase further (Harrod, 1939; Domar, 1946; Capello, 2007).

Up to the 1990s the mainstream economics did not pay great attention to the spatial connections of economic activities. Based on the neoclassical and endogenous growth theories, the national economic policies and the country specific factors have a significant effect on the regional convergence (Kertész, 2003). Hence, the socio-economic activities are localizable, and each has an exact geographic location; the locational characteristics have a significant effect on their dispersion (Benedek - Kocziszky, 2013). The analysis of spatial economics and location theories has got long past (Krugman, 1999). Von Thünen's isolated city theory is contemporaneous with Ricardo's comparative advantages theory, and the other location theories also have got long history. As a consequence of the spatial factors' significance, new approaches have appeared from the 1990s to explain the process of regional economic growth and convergence (like the new economic geography as a new issue in spatial economics) which brought significant changes in the examination of spatial distributions.

There was an increasing need for measuring the role and effects of spatial connections from that time. The spatial econometrics is a part of econometrics which examines the spatial aspects (interactions, autocorrelation, and spatial structures) in cross-sectional, time series and panel models (Anselin, 1999). In this research I also wanted to examine the spatial patterns of given indicators (income and EU supports) and check the significance of spatial connections; that is why I have also applied spatial econometric methods through the analysis. 


\section{Former research statements, empirical evidences}

In the above-mentioned theoretical convergence models the researchers have made analyses mainly on country or regional level, but there is a need also for measuring lower levels of inequalities. Before the regional level analysis, I have made some country level examination about the spatial dependency of given indicators (Szendi, 2015a; 2015b; 2016) to see the significance of the spatial models. I have examined the spatial patterns of territorial income in Hungary for 2012-2013, based on micro regional level data, and have made a statement that the territorial concentration of income is observable. The income dispersion shows homogenous, high developed north - north-western path (Vas, Györ-Moson-Sopron, Komárom-Esztergom, Fejér and Pest counties, and the capital), and there is a highly developed Budapest-Miskolc, Budapest-Győr, Budapest-Szeged, Budapest-Keszthely, and Budapest-Pécs axis. Along these axes the territorial income is the highest. The least developed territories can be found in the north-eastern - northern part of Hungary (Borsod-AbaújZemplén, Nógrád, Szabolcs-Szatmár-Bereg counties), and in Békés county. These territories are in terms of accessibility and of the western capital-intensive enterprises peripheral ones, in several cases, only the county centre has significant economic potential (Szendi, 2016). Also, Pénzes (2011) has stated that the spatial border line of development and lag can be found along the Balassagyarmat- Békéscsaba axis. So, I think that the analysis of the Northern Hungarian region is an actual issue.

I have also analyzed the spatial autocorrelation, and the role of spatial connections in the case of the country level territorial income, also based on micro regional data. In Hungary, the taxable income per capita showed medium strong, positive spatial autocorrelation among the micro-regions in 2013 (similar to the analysis of Dusek, 2004). It can be verified by the low value of pseudo-p (0.001) and the high value of z-score (12.79). According to the Local Moran analysis, 117 of the examined 168 micro-regions did not show significant autocorrelation. The members of the high-high cluster can be found mainly in the Central Hungarian and Central Transdanubian region. These are highly developed territories according to the income per capita. To the low-low cluster, 22 territories can be clustered, with much lower income than the average, and their neighbours are also underdeveloped areas. They are mostly in South and North-eastern Hungary (this last class can be underlined also by the analysis of Jakobi, 2011). The high-low cluster, which indicates emerging areas, has two parts (both county centres), in Hajdú-Bihar County the micro-region of Debrecen and in Szabolcs-Szatmár-Bereg County the micro-region of Nyíregyháza (Szendi, 2016). The spatial outlier role of these two micro-regions can be verified also by the settlement-level analysis of Tóth and Nagy (2013). 


\section{DATA AND METHODOLOGY}

\section{Aim and focus}

The aim of this recent research is to analyze the spatial dispersion of the territorial income per capita and the EU supports among the settlements of the Northern Hungarian region. I also would like to examine how strong is the connection between the two indicators and what kind of role has the neighbourhood relations. The basic research questions are:

- What kind of spatial patterns can be verified in the case of territorial income and EU supports?

- Is there any connection between a settlement's income and EU support level?

- What kind of role has the neighbourhood relations, and is there any similarity in the spatial autocorrelation clusters of the two indicators?

Through the analysis, I have defined two special settlement categories to focus on which are the small- and medium-sized cities and the settlements of the most disadvantaged areas which need a complex development program. The covered area of special categories can be seen on the following Figure 1.

Figure 1 The area of examined special categories

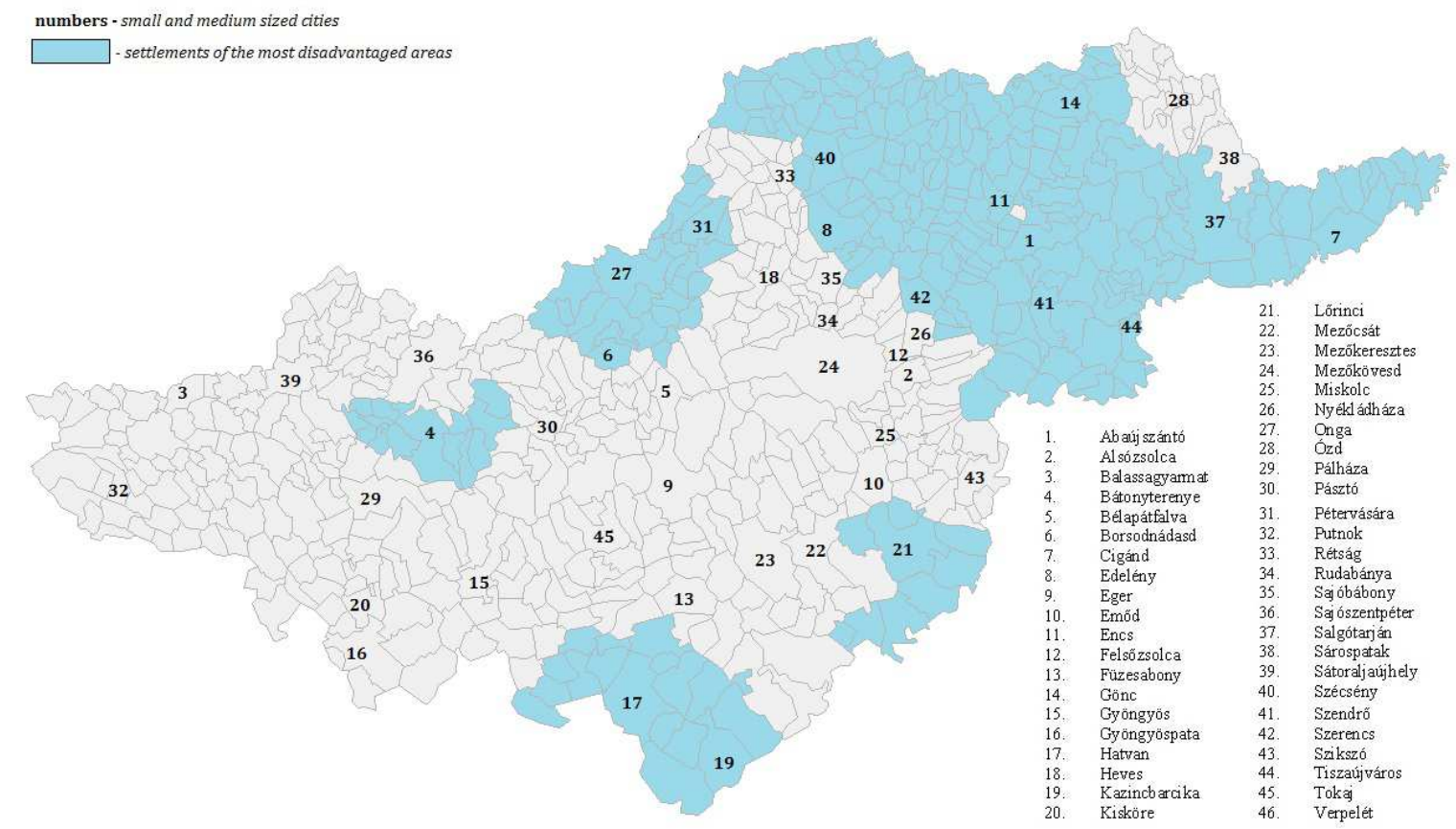

Source: own compilation

\section{METHODOLOGY}

By the analysis of spatial patterns and autocorrelation, I have used correlation analysis, inequality indices and the methods of spatial econometrics. To measure the level of 
inequalities, I have applied the Dual indicator and the Hoover index. The Dual indicator is a measure of spatial polarity and can be calculated as follows:

$$
\text { Dual indicator }=\frac{\text { mean of values above the average }}{\text { mean of values below the average }}
$$

The Hoover index (also known as Robin Hood index) measures the differences of the spatial income distribution. It measures the share of a given community's income that would have to be redistributed (taken from the richer part of the population and given to the poorer part) for reaching income equality (UN, 2015). It is also known as the longest vertical distance in the Lorenz curve. The Hoover index can be calculated as follows:

$$
h=\frac{\sum_{i=1}^{n}\left|x_{i}-f_{i}\right|}{2}
$$

where $\boldsymbol{x}_{\boldsymbol{i}}$ is the share of region " $\mathrm{i}$ " from the value of a given " $\mathrm{x}$ " variable, $\boldsymbol{f}_{\boldsymbol{i}}$ is the share of region "i" from the value of a given "f" variable, $\Sigma \boldsymbol{x}_{\boldsymbol{i}}=100$ and $\Sigma \boldsymbol{f}_{\boldsymbol{i}}=100$.

Spatial autocorrelation is a method for examining spatial interactions. It will be analyzed in this method whether the spatial distribution of dates is random or it follows some regular pattern (Dusek, 2004). Autocorrelation means that "high or low values for a random variable tend to cluster in space (positive spatial autocorrelation), or locations tend to be surrounded by neighbours with very dissimilar values (negative spatial autocorrelation)” (Anselin-Bera, 1998, p. 241).

The Moran I index (elaborated by Moran, 1950) is one of the most often used measurement methods of spatial autocorrelation. The index can be calculated with the help of the following equation:

$$
\boldsymbol{I}=\left(\frac{\boldsymbol{N}}{\sum \boldsymbol{D}_{\boldsymbol{i j}}}\right) * \frac{\sum \sum\left(\boldsymbol{x}_{\boldsymbol{i}}-\overline{\boldsymbol{x}}\right) *\left(\boldsymbol{x}_{\boldsymbol{j}}-\overline{\boldsymbol{x}}\right) * \boldsymbol{D}_{\boldsymbol{i}}}{\sum\left(\boldsymbol{x}_{\boldsymbol{i}}-\overline{\boldsymbol{x}}\right)^{2}}
$$

where is $\boldsymbol{D}_{\boldsymbol{i}}$ the matrix of neighbourhood connections, and $\mathrm{N}$ the number of territories. When $I>\frac{-1}{N-1}$ then there is positive; when $I<\frac{-1}{N-1}$ there is a negative spatial autocorrelation, and when $I=\frac{-1}{N-1}$ there is no autocorrelation among the territories (Dusek, 2004). 
The Local Moran I index is the local measure of spatial autocorrelation; it gives an exact value for each of the examined territories. The negative values of the index show negative while the positive values indicate positive spatial autocorrelation. It also draws up where the high and low values are concentrating in space (hot and cold spots) and where are the socalled spatial outliers (Tóth-Nagy, 2013).

In the literature, it is well-known that the correct choice of the spatial weights' matrix is critical (Harris-Kravtsova, 2009). It expresses the assumed spatial structure of variables in the model (Gerkman - Ahlgren, 2011, p. 1). According to Bhattacharjee and Jensen-Butler (2013, p. 618): "the choice of weights is frequently arbitrary, there is substantial uncertainty regarding the choice, and empirical results vary considerably according to the choice of spatial weights."

Several methods in the literature define the spatial weights matrix. The simplest matrix is when the neighbouring territories are marked with 1, and the territories which are not neighbours of each other are marked with 0. It contains less distortion when we use rowstandardized matrices, where the sum of values in a row is equal to 1 (Nemes Nagy, 2005). By the analysis of grids, two types of matrices can be defined: rook and queen contiguity. The basic difference between these is that by rook contiguity the territories are sharing common borders, while by the queen contiguity beside the common borders also common points are permitted as neighbourhood criteria.

There are also other methods to define neighbourhood connections, like the threshold distance, or nearest neighbour method, or the Euclidean distance based methods. In the practice the most commonly used methods are the queen contiguity $(38 \%)$, then the distance based methods (29\%), after the combination of these two (14\%), and other methods, like the nearest neighbour method (Abreu et al. 2005).

\section{Data}

In my research, I have made the analysis for 2014, which was the latest year where I had all of the dates available. By the analyses, my basic data sources were the data base of the Hungarian Central Statistical Office, the dates of the Unified Monitoring Information System, and the dates of the National Regional Development and Spatial Planning Information System. The sources of the applied data can be seen in a more detailed way on the following Table 1. 
Table 1 Applied data sources of the analysis

\begin{tabular}{|c|c|c|}
\hline Indicator & Measure & Data source \\
\hline $\begin{array}{l}\text { Taxable income per capita/ per } \\
\text { employee }\end{array}$ & HUF/capita & $\begin{array}{ll}\text { - } & \text { Hungarian Central Statistical } \\
\text { Office: Dissemination database } \\
\text { - National Regional Development } \\
\text { and Spatial Planning Information } \\
\text { System }\end{array}$ \\
\hline Obtained EU support per capita & HUF/capita & $\begin{array}{l}\text { - Unified Monitoring Information } \\
\text { System - National Development } \\
\text { Agency, Hungary } \\
-\quad \text { palyazat.gov.hu }\end{array}$ \\
\hline Population & $\begin{array}{l}\text { number of } \\
\text { inhabitants }\end{array}$ & Hungarian Central Statistical Office \\
\hline
\end{tabular}

Source: own compilation

\section{RESULTS}

\section{Spatial distribution of the indicators}

In this recent research, I have analyzed the spatial distribution of the taxable income per capita and the obtained EU support per capita among the settlements of the Northern Hungarian region. According to the results a statement can be made that in the case of the incomes, the most developed territories can be found mainly in the central part of the region, on the one hand along the path of the motorway and on the other hand in the county centres and their agglomeration. In these areas, the per capita income is relatively high. Among the county centres, Miskolc has outstanding position hence, in this case, is the most extensive the highly developed circle around the city. This highly developed area reaches on the north to Sajószentpéter, on the south to Harsány and Emőd, on the east to Szikszó and on the western part to Répáshuta and Bükkszentkereszt (about almost 20-kilometre radius around the centre of Miskolc). This area is in the case of Eger relatively smaller because it reaches on the north to Felsőtárkány, on the south to Maklár, on the east to Noszvaj and on the western part to Egerszólát (about 11.5-kilometre radius around the centre of Eger). The highly developed area is the smallest in the case of Salgótarján, where only Karancsalja and Somoskőújfalu belong to it (only 8-kilometre radius).

The highest income in the region can be identified in the following eight settlements: Pálosvörösmart, Markaz, Szarvaskö, Teresztenye, Kistokaj, Sajószöged, Sajóörös and Tiszaújváros, which common character is that not only the income of inhabitants is very high, but also the employment rate. The situation of Teresztenye is somehow specific; hence it is a very small village (it had only 28 inhabitants in 2014) in the micro-region of Cserehát, where the extremely high income can be the result of good rural tourism activity. The settlement can be from this aspect a good example in this relatively underdeveloped, peripheral area. 
Figure 2 Distribution of the taxable income per capita (settlements of the Northern Hungarian region), 2014

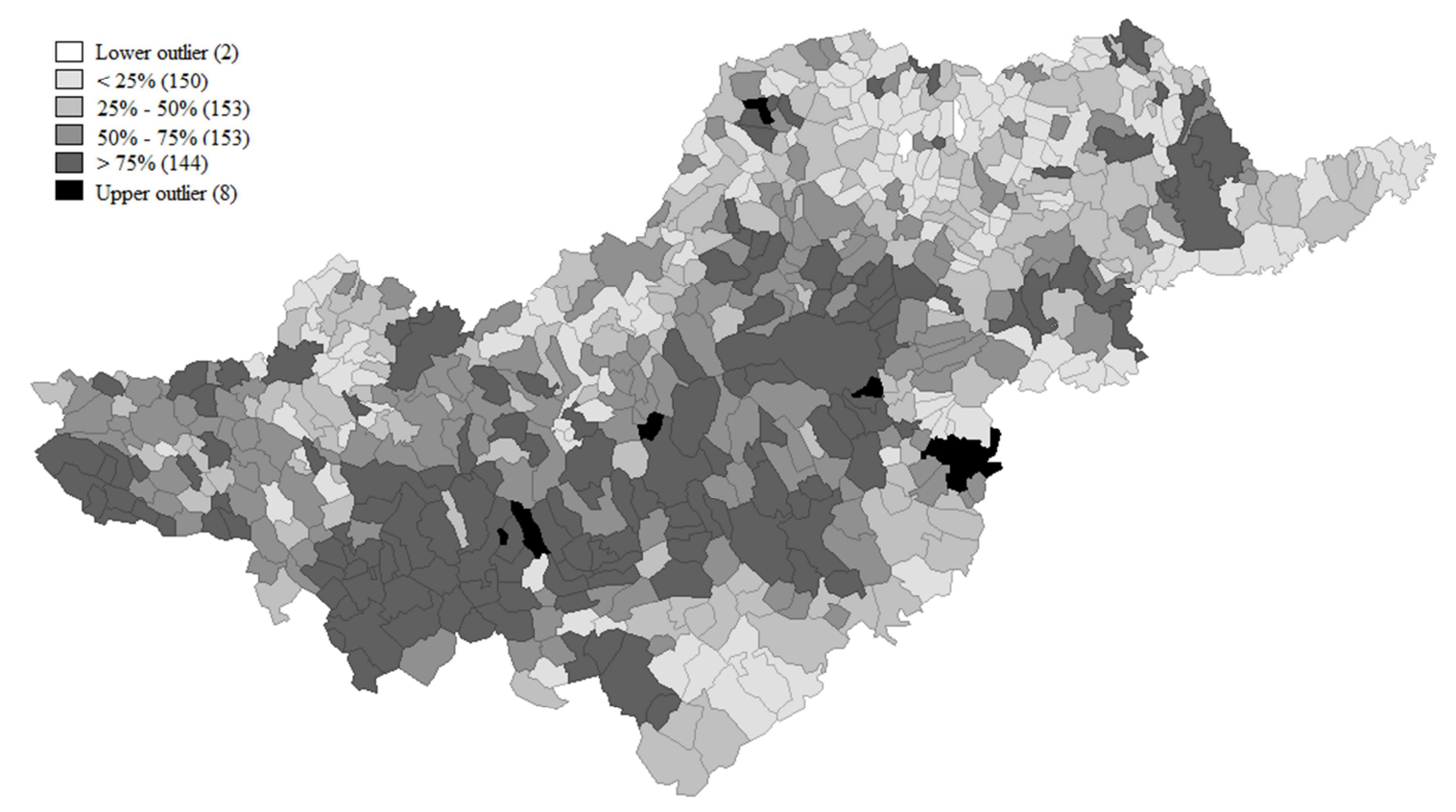

Source: own compilation

The lowest income of the region can be observed in Gadna and Csenyéte villages, where also the number of full-time employees among the population is the lowest (in both cases below 20\%). Besides these two small villages, the income is the lowest in the rural area of Cserehát and Zemplén, $60 \%$ of the settlements with the lowest values can be found in these territories. Also, Pénzes (2011, p. 186) has made a statement that there are several peripheral settlements in the Cserehát micro-region, where this underdeveloped situation can be the result of the many small villages existing in the area, of the aging society, of the relatively high unemployment rate, and the increase of roma population.

In the case of the obtained EU supports there are more hot spots in the region as observed by the income of settlements. There is a sum of 57 so-called upper outliers in the space where the obtained amount of EU support is relatively high (emerging areas). Although the supports are concentrating mainly in the cities, the small villages of Abod and Alsóregmec have received the most EU grant in the region in per capita relation. The obtained amount was 18100 and 29978 thousand HUF per capita respectively. The reason for this can be that these settlements have only 258 and 224 person population in 2014, but they have received some big projects (Abod 6 and Alsóregmec 3). As a result of it, the support amount per capita is very high.

In the region, the average amount of EU grants per capita reaches almost 575700 HUF, instead of the fact that there are 52 settlements in the Northern Hungarian region which did not obtain EU support in the period. 
Figure 3 Distribution of the EU supports per capita (settlements of the Northern Hungarian region), 2014

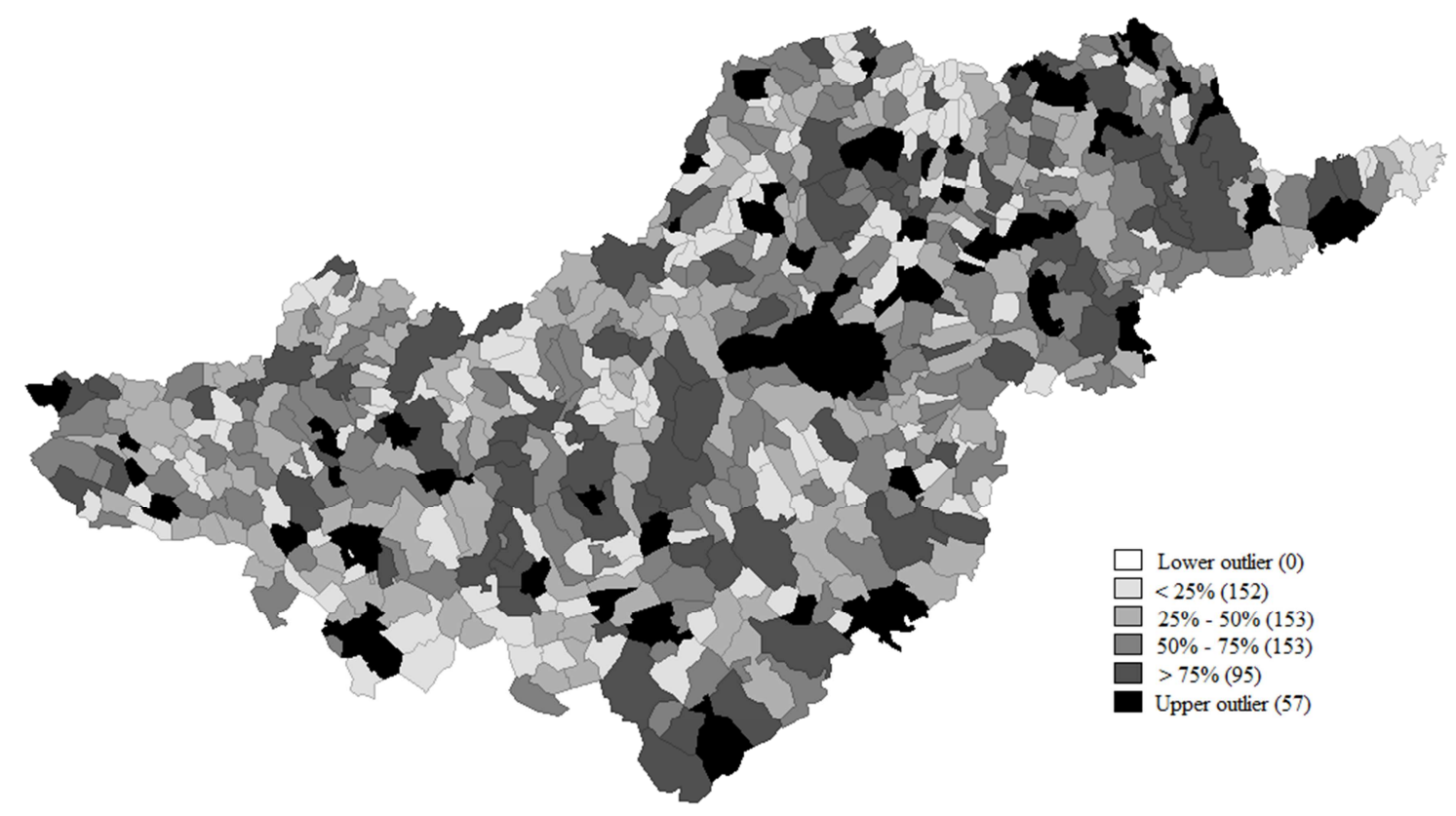

Source: own compilation

By the examination of the so-called special categories I could make a statement that the small- and medium-sized cities have a significant role in the distribution of supports. 47 cities from the summa 610 settlements $(7.7 \%)$ got the $68.6 \%$ of all supports in the given time period which shows an unequal distribution. The relatively lower absorption capacity of the peripheral regions of Cserehát and Zemplén can be observed in the pattern of the supports; hence almost $30 \%$ of the settlements with zero EU support belong to these areas. It is also observable that the gained EU supports are not always concentrating in the biggest/most populated cities; hence several smaller settlements got relatively high support amount per capita (like Tiszadorogma, Tiszabábolna, Kisköre, Alsógagy, or Szakácsi). It would be also notable to see, how many projects these settlements received, to compare the dates. I have taken a closer look at this question for the Top 5; most supported settlements in the region, which general character is that they are villages, with relatively low population numbers. From the dates, I could identify that in two villages from the Top 5 (Alsóregmec and Szakácsi) the number of supported projects is very low, 3 and 2 respectively. It means that here the average support amount per project is relatively high: 1.271 billion and 0.589 billion HUF. This amount is a bit lower in the case of the three remaining settlements from the Top 5, as here the number of projects is higher (Abod: 6; Hollókő and Bodroghalom: both 8 projects). The average support amounts per project are respectively 1.114 billion, 0.342 and 1.215 billion HUF. It is significant to mention that because of the qualitative differences of 
EU grants the purely quantitative analysis is not always adequate to differentiate the settlements' situation, but in this recent research I did not deal with the qualitative aspects.

It is an interesting fact that there are some similarities in the ranking of settlements based on their income level and EU grant absorption capacity (Table 2). Hence, four of the last ten settlements in the ranking belong from both aspects into the worst, most underdeveloped group. In these settlements, not only the income levels are very low, but also the communities' initiatives are not so effective, hence they could not get EU supports. In the case of Gadna and Kiscsécs, the number of applied projects was zero in the period, while in Bódvalenke and Csenyéte there were 1 and 2 project applications, but they did not receive any support.

Table 2 Ranking of settlements based on their income level and EU support absorption capacity

\begin{tabular}{|c|l|r|r|l|r|}
\hline \multicolumn{2}{|c|}{$\begin{array}{c}\text { Ranking based on the territorial income } \\
\text { level }\end{array}$} & \multicolumn{3}{c|}{$\begin{array}{c}\text { Ranking based on the obtained EU } \\
\text { grants }\end{array}$} \\
\hline No. & \multicolumn{1}{|c|}{ Settlement } & $\begin{array}{c}\text { Income } \\
\text { (HUF/capita) }\end{array}$ & No. & \multicolumn{1}{c|}{ Settlement } & $\begin{array}{c}\text { EU grants } \\
\text { (HUF/capita) }\end{array}$ \\
\hline 1 & Sajöörös & 2863236 & 1 & Abod & 29978283 \\
\hline 2 & Teresztenye & 2739693 & 2 & Alsóregmec & 18169638 \\
\hline 3 & Markaz & 2682870 & 3 & Hollókö & 7772160 \\
\hline 4 & Pálosvörösmart & 2603557 & 4 & Szakácsi & 7703015 \\
\hline 5 & Tiszaújváros & 2557807 & 5 & Bodroghalom & 6883414 \\
\hline 6 & Sajószöged & 2553715 & 6 & Füzér & 6742653 \\
\hline 7 & Kistokaj & 2498535 & 7 & Demjén & 6495474 \\
\hline 8 & Szarvaskö & 2493445 & 8 & Regéc & 5891011 \\
\hline 9 & Visonta & 2422040 & 9 & Apc & 5702187 \\
\hline 10 & Gyöngyössolymos & 2391321 & 10 & Jósvafó & 5333879 \\
\hline & & & & 0 \\
\hline 601 & Terpes & 743646 & 601 & Márkháza & 0 \\
\hline 602 & Nyésta & 741019 & 602 & Pere & 0 \\
\hline 603 & Tornanádaska & 737848 & 603 & Beret & 0 \\
\hline 604 & Kiscsécs & 734856 & 604 & Szászfa & 0 \\
\hline 605 & Fáj & 692806 & 605 & Pusztaradvány & 0 \\
\hline 606 & Szakácsi & 691566 & 606 & Pamlény & \\
\hline 607 & Bódvalenke & 618257 & 607 & Kiscsécs & \\
\hline 608 & Felsöregmec & 585062 & 608 & Bódvalenke & \\
\hline 609 & Gadna & 564607 & 609 & Gadna & \\
\hline 610 & Csenyéte & 403973 & 610 & Csenyéte & \\
\hline Source: owncompilation & & & & 0 \\
\hline
\end{tabular}

Source: own compilation

From the connection observed by the ranking of settlements, I have assumed that there might be some relation/connection between the two indicators, that is why I have examined the correlation between the settlements' income and EU grants per capita. The results are summarized in the following Table 3. 
Table 3 Correlation of income and EU grants

\begin{tabular}{|c|c|c|}
\hline \multicolumn{3}{|c|}{ Hungary LAU1 } \\
\hline \multirow{3}{*}{ Income per capita } & Pearson Correlation & Gained EU grants per capita \\
\cline { 2 - 3 } & Sig. (2-tailed) & $-0.208^{* *}$ \\
\cline { 2 - 3 } & $\mathrm{N}$ & 0.006 \\
\hline \multicolumn{3}{|c|}{ Northern Hungarian region LAU2 } \\
\hline \multirow{3}{*}{ Income per capita } & Pearson Correlation & Gained EU grants per capita \\
\cline { 2 - 3 } & Sig. (2-tailed) & 0.21 \\
\cline { 2 - 3 } & $\mathrm{N}$ & 0.599 \\
\hline \multirow{2}{*}{$* *$ Correlation is significant at the 0.01 level (2-tailed). } \\
\hline
\end{tabular}

In the Hungarian micro regional level there is a significant, but weak negative correlation between the income per capita and the gained EU grants, at the same time this is not significant in the case of the Northern Hungarian region's settlements. I have taken a closer look at the "special categories" and have seen that in the case of the small- and medium-sized cities there is also a negative correlation between the two indicators (-0.116), and it was also non-significant. By the settlements of the most disadvantaged areas there was a significant but very weak negative correlation between the indicators $\left(-0.009^{*}\right)$, so in this case, there might be some connection between the income and EU grants.

I have also examined the territorial inequality indices in the region to see what kind of differences can be observed by the two indicators. I have calculated the Dual indicator and the Hoover index of 2013.

a) By the Dual indicator there is a 1.472-fold difference between the average of the more developed (income is higher than the mean) and less developed (income is lower than the mean) territories in case of income. This ratio is even higher by the EU grants, hence an 11.084-fold difference can be observed among the settlements.

b) This tendency can be noticed also by the analysis of the Hoover index, which value is 8.83 by the income per capita and 34.2 in the case of gained EU grants. It means that by the EU supports, $34.2 \%$ of all supports would have to be redistributed from the more developed to the least developed areas to achieve a state of perfect equality. 
So the above-examined values of inequality measures have shown a greater gap among the settlements based on their EU supports.

\section{Spatial autocorrelation}

I have also analyzed the role of spatial interactions in the Northern Hungarian region to see whether the spatial autocorrelation has significance in the distribution of indicators. I have made the examination with the use of two different neighbourhood matrices to prove the validity of the analysis: the queen-contiguity and the nearest neighbours' method (with six neighbours). I have made both calculations with 999 permutations to eliminate the random error, and have tested the methods of LISA. By the exact analysis, I have focused on the results of the 6 nearest neighbours' matrix.

Table 4 Local Moran clusters of income and EU grants

\begin{tabular}{|c|c|c|c|c|}
\hline & \multicolumn{2}{|c|}{ income per capita } & \multicolumn{2}{|c|}{ EU grants per capita } \\
\hline & queen contiguity & $\begin{array}{c}\text { nearest neighbours } \\
\text { method (6) }\end{array}$ & queen contiguity & $\begin{array}{c}\text { nearest neighbours } \\
\text { method (6) }\end{array}$ \\
\hline Moran I & 0.333748 & 0.318045 & 0.04491 & 0.053027 \\
\hline pseudo-p value & 0.001 & 0.001 & 0.021 & 0.018 \\
\hline Z score & 13.7783 & 14.1122 & 2.1682 & 2.8926 \\
\hline $\begin{array}{l}\text { Local Moran } \\
\text { clusters }\end{array}$ & $\begin{array}{l}\text { HH: 76; LL: } 56 \text {; } \\
\text { LH: 17; HL: } 14 .\end{array}$ & $\begin{array}{l}\text { HH: 70; LL: } 63 \text {; } \\
\text { LH: } 17 \text {; HL: } 24 .\end{array}$ & $\begin{array}{l}\text { HH: 15; LL: } 33 \text {; } \\
\text { LH: 25; HL: } 4 .\end{array}$ & $\begin{array}{l}\text { HH: 32; LL: 48; } \\
\text { LH: } 18 ; \text { HL: } 16 .\end{array}$ \\
\hline
\end{tabular}

Note: HH - high-high; LL - low-low; LH - low-high; HL - high-low.

Source: own compilation

Based on the model values, there is a weak, positive and significant spatial autocorrelation among the Northern Hungarian region's settlements in the case of the income, so the highand low-income values are clustering in the space.

Taking a closer look at the Local Moran clusters of the income per capita, I could identify that the elements of the High-high cluster are clustering mainly in the central zone of the region, along the path of the M3 motorway, while the members of the Low-low cluster are grouping principally in the northern and north-eastern periphery of the region (Figure 4). 63\% of the settlements in the Cserehát and Zemplén micro-region belong to this cluster (mainly in the districts of Cigánd, Gönc, Encs, Szikszó and Edelény). 
Figure 4 Local Moran clusters of income per capita, Northern Hungarian region, 2014.

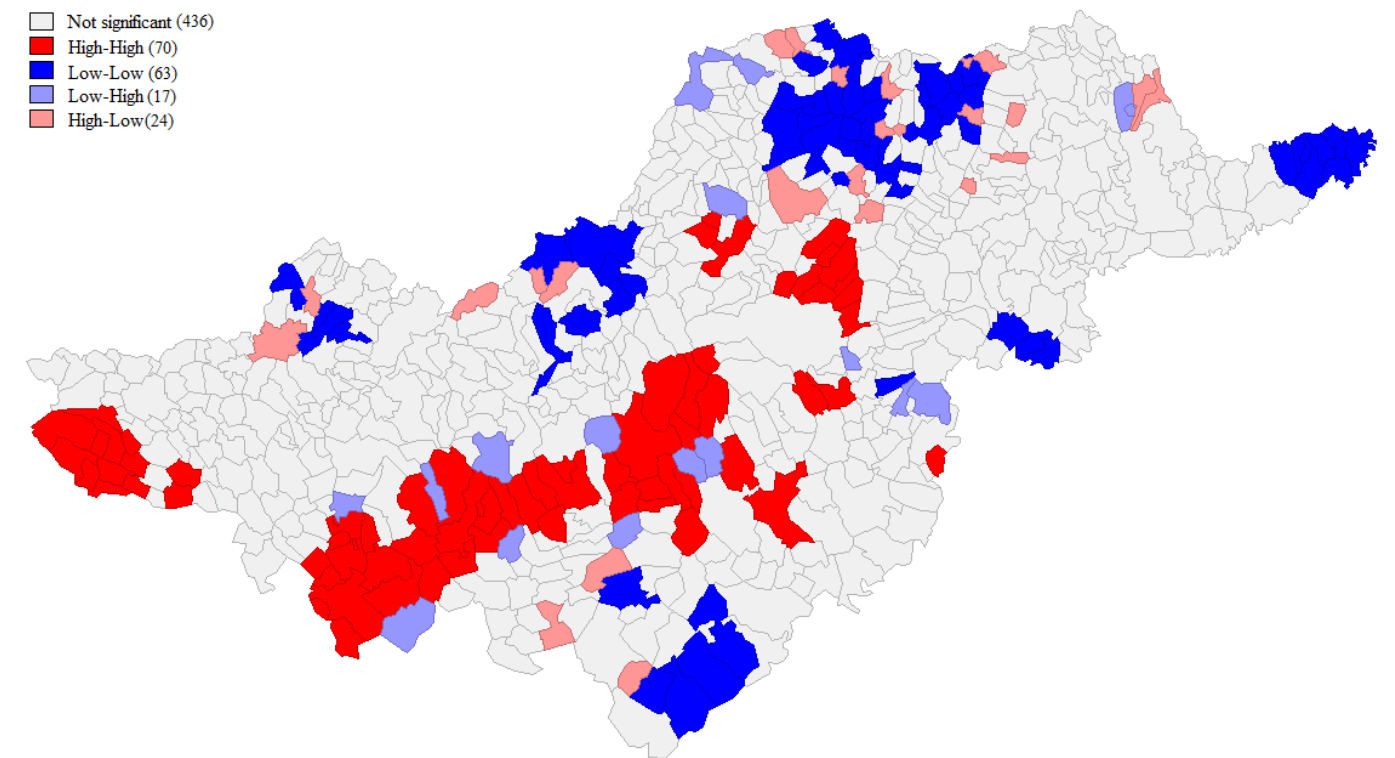

Source: own compilation

The parts of the High-low and Low-high cluster are concentrating mainly in the peripheries of the High-high and Low-low clusters. Some members of the High-low cluster are emerging areas like Edelény, Homrogd, Alsóregmec, Szécsény or Hevesvezekény, while members of the Low-high cluster are settlements with relatively lower-income than their neighbours, like Aggtelek, Sajókaza, Kesznyéten, Egerbakta or Parád.

In the case of the EU grants, the spatial autocorrelation is also significant but relatively weaker than observed by the income. So here the neighbourhood connections have a smaller effect on the dispersion of dates.

According to the comparison of the Local Moran patterns, there is a great similarity among the clusters of income and EU supports, hence the $93.48 \%$ of the small- and medium-sized cities can be ruled into the same cluster according to both indicators (mainly to the High-high cluster), while in the case of the most disadvantaged areas' settlements $96.16 \%$ of the territories belong to the same group according both indicators (basically to the Low-low, or High-low cluster). So, the differences between the most and least developed territories observed by the income per capita can be verified also in the case of gained EU supports, hence the areas characterized by small villages and aging societies in Zemplén and Cserehát have relatively low absorption capacity, which strengthens their peripheral situation.

The above-mentioned similarity of Local Moran clusters can be seen in the case of smalland medium-sized cities on the following Table 5 in a more detailed way. There are only three cities where the cluster membership or the spatial autocorrelation's significance differ from each other regarding the income and EU supports, and the remaining 93.48\% of the region's 
cities belong to the same class by both indicators. The three outlier cities' situation is as follows: Mezőkövesd and Tiszaújváros: there is no significant local autocorrelation by the income, but by the EU supports they can be grouped into the High-high cluster, so these two cities and their neighbours also have very successful application activity. The case of Cigánd is a little different. In this city, the income's spatial autocorrelation is also non-significant, but based on the EU support it belongs to the High-low cluster; because its application activity is quite good (83 project applications, from which 43 successful). With this success ratio, Cigánd can emerge from its neighbourhood.

Table 5 Similarity of Local Moran clusters by the small- and medium-sized cities

\begin{tabular}{|c|c|c|c|c|c|}
\hline City & $\begin{array}{c}\text { Clusters of } \\
\text { income }\end{array}$ & $\begin{array}{l}\text { Clusters of } \\
\text { EU support }\end{array}$ & City & $\begin{array}{c}\text { Clusters of } \\
\text { income }\end{array}$ & \begin{tabular}{|c|}
$\begin{array}{c}\text { Clusters of EU } \\
\text { support }\end{array}$ \\
\end{tabular} \\
\hline Abaújszántó & & & Miskolc & & \\
\hline Alsózsolca & & & Nyékládháza & $\mathrm{HH}$ & $\mathrm{HH}$ \\
\hline Balassagyarmat & & & Onga & & \\
\hline Bátonyterenye & & & Ózd & & \\
\hline Bélapátfalva & & & Pálháza & & \\
\hline Borsodnádasd & & & Pásztó & & \\
\hline Cigánd & & $\mathrm{HL}$ & Pétervására & & \\
\hline Edelény & $\mathrm{HL}$ & $\mathrm{HL}$ & Putnok & & \\
\hline Eger & $\mathrm{HH}$ & $\mathrm{HH}$ & Rétság & & \\
\hline Emőd & & & Rudabánya & & \\
\hline Encs & & & Sajóbábony & & \\
\hline Felsőzsolca & $\mathrm{HH}$ & $\mathrm{HH}$ & Sajószentpéter & & \\
\hline Füzesabony & & & Salgótarján & & \\
\hline Gönc & & & Sárospatak & & \\
\hline Gyöngyös & $\mathrm{HH}$ & $\mathrm{HH}$ & Sátoraljaújhely & & \\
\hline Gyöngyöspata & $\mathrm{HH}$ & $\mathrm{HH}$ & Szécsény & $\mathrm{HL}$ & $\mathrm{HL}$ \\
\hline Hatvan & $\mathrm{HH}$ & $\mathrm{HH}$ & Szendrö & LL & $\mathrm{LL}$ \\
\hline Heves & & & Szerencs & & \\
\hline Kazincbarcika & & & Szikszó & & \\
\hline Kisköre & & & Tiszaújváros & & $\mathrm{HH}$ \\
\hline Lörinci & $\mathrm{HH}$ & $\mathrm{HH}$ & Tokaj & & \\
\hline Mezőcsát & & & Verpelét & $\mathrm{HH}$ & $\mathrm{HH}$ \\
\hline Mezőkeresztes & $\mathrm{HH}$ & $\mathrm{HH}$ & & & \\
\hline Mezőkövesd & & $\mathrm{HH}$ & & & \\
\hline
\end{tabular}

Source: own compilation

Starting from the results of the Local Moran patterns I have computed the so-called conditional maps in the case of the Northern Hungarian region which can describe and compare graphically the dispersion of variables with the use of a coordinate system. "The 
purpose of conditioning is to assess the extent to which there is a suggestion of systematic differences in the variable distribution among the sub-regions." (Anselin, 2005, p. 91). A conditional map consists of 9 micro maps; each computed for a subset of the observations. Three intervals for each variable define the subsets (Anselin, 2005, p.70).

In the case of this recent research, the horizontal axis contains the income per capita dates and the vertical axis the gained support amount per capita. The category variable is the population size of a given settlement, which determines the territories' clusters (Figure 5).

Figure 5 Conditional map of variables (2014)

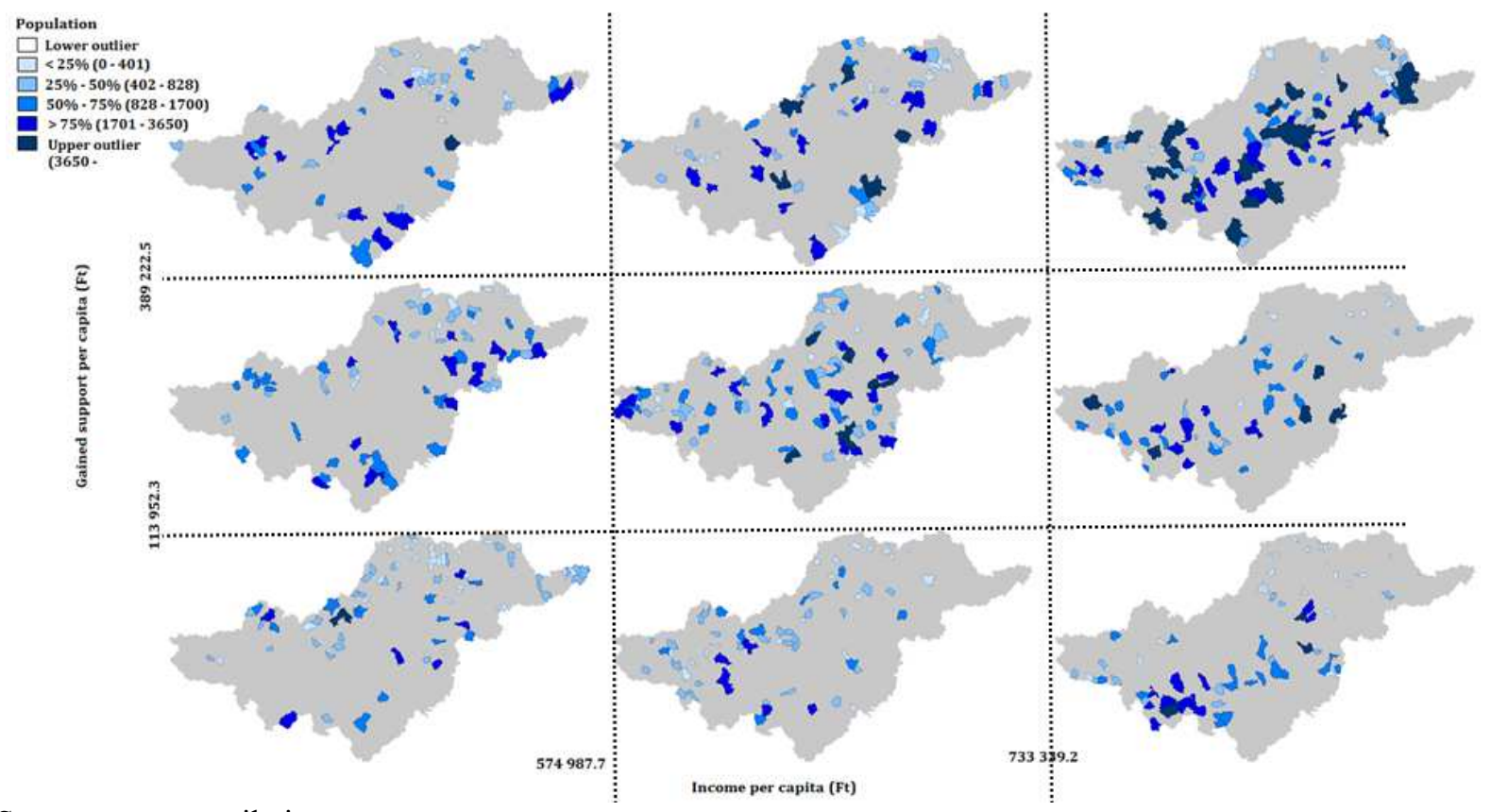

Source: own compilation

At the first overview of the maps, it is observable that the bigger cities can be found mainly in the cluster, where both the income per capita and the gained support amount is the highest (right upper group); all county centres (Miskolc, Eger, and Salgótarján) can be found in this class. The small- and medium-sized cities are concentrating most of the cases also in this cluster or in that where the income is about the average of the region, but the support amount reaches the highest level (central upper group). There are only some exceptions from smalland medium-sized cities which are not members of these two clusters like Sajószentpéter and Putnok (members of the cluster where the income and the support amount are also average central group), or Emöd and Tiszaújváros (members of the right central cluster where the income level belongs to the highest class but the support amount is about the average). 
$66 \%$ of the settlements of the most disadvantaged areas belong to the clusters where the gained EU support per capita varies from the lowest to the highest level, but their income level is relatively low (left three clusters). There are only a few settlements of this special category where the gained support amount reaches the highest levels and common character of these is that they have bigger population size. Only some small villages of the most disadvantaged areas could reach high support amounts (like Lak, Felsővadász, Nagyrozvágy, Krasznokvajda or Abaújlak which have on the average 6-7 supported projects).

\section{SUMMARY}

In this recent research, I have analyzed the territorial differences of the per capita income and the gained EU supports in the Northern Hungarian region, to see what kind of differences or inequalities can be verified in these indicators.

Regarding the results, the existence of territorial inequalities is a significant problem also in the case of Hungary with special regards on the settlements of the Northern Hungarian region. The Local Moran clusters forming through the analysis of EU supports and income per capita show significant similarity, $93.48 \%$ of the small- and medium-sized cities, and $96.16 \%$ of the settlements of the most disadvantaged areas can be grouped into the same cluster according to both indicators. I could state that in the areas with significant spatial autocorrelation most of the cities can be grouped into the High-high cluster, while the greatest part of the settlements of the most disadvantaged areas belongs to the Low-low or High-low clusters.

So, the difference of the incomes can be observed also in the level of EU supports, the territories of Cserehát and Zemplén characterized by small villages, and aging population have relatively weak absorption capacity, which strengthens their peripheral situation. The EU supports' distribution is unequal also in the city-rural dimension in the Northern Hungarian region, hence 47 cities of the sum 610 settlements got the $68.6 \%$ of area's EU support in the given time period.

\section{REFERENCES}

Abreu, M., De Groot H. L. F., \& Florax, R. J. G. M. (2005). "Space and Growth: A Survey of Empirical Evidence and Methods." Tinbergen Institute Discussion Paper, No. 04-129/3. Anselin, L. (1999). Spatial econometrics. In B. Baltagi (Ed.), Companion in theoretical econometrics (pp. 310-330). Oxford: Basil Blackwell.

Anselin, L. (2005). Exploring Spatial Data with GeoDaTM: A Workbook. University of Illinois: Center for Spatially Integrated Social Science. 
Anselin, L., \& Bera, A. K. (1998). Spatial dependence in Linear Regression Models with an Introduction to Spatial Econometrics. Statistics textbooks and monographs, 155, 237290.

Barro, R. J. (1991). Economic Growth in a Cross Section of Countries. The Quarterly Journal of Economics, MIT Press, 106(2), 407-43.

Barro, R. J., \& Sala-i-Martin, X. (1992). Convergence. Journal of Political Economy, 100(2), 223- 251 .

Benedek, J., \& Kocziszky, Gy. (2013). Bevezetés a regionális politikába. [Introduction to regional policy.] Miskolc: Miskolci Egyetemi Kiadó.

Benedek, J., \& Kurkó, I. (2011). Evolution and Characteristics of Territorial Economic Disparities in Romania. Theory Methodology and Practice, 7(1), 5-15.

Bhattacharjee, A., \& Jensen-Butler, Ch. (2013). Estimation of the spatial weights matrix under structural constraints. Regional Science and Urban Economics, 43(4), 617-634.

Capello, R. (2007). Regional economics. Routledge, Taylor and Francis group.

Domar, E. D. (1946). Capital Expansion, Rate of Growth, and Employment. Econometrica, $14(2), 137-147$.

Dusek, T. (2004). A területi elemzések alapjai. [Basics of spatial analysis.] Regionális tudományi tanulmányok 10. Budapest: ELTE Regionális Földrajzi Tanszék, MTAELTE Regionális Tudományi Kutatócsoport.

European Commission (2016). Eurostat regional yearbook 2016. Luxembourg: Publications Office of the European Union.

Gerkman, L., \& Ahlgren, N. (2011). Practical Proposals for Specifying k-Nearest Neighbours Weights Matrices. Hanken School of Economics, Working Papers 555.

Harris, R., \& Kravtsova, V. (2009). In Search of 'W'. SERC: Discussion Paper 17.

Harrod, R. F. (1939). An Essay in Dynamic Theory. The Economic Journal, 49(193), 14-33.

Jakobi, Á. (2011). Examining Neighbourhood Effects in Regional Inequalities of Hungary: A GIS-based approach from topological relations to neighbourhood heterogenity. Romanian Review of Regional Studies, VII.(1), 53-62.

Kertész, K. (2003). Felzárkóznak-e a kevésbé fejlett országok az Európai Unióban...? [Can the less developed contries converge in the European Union?] Budapest: ICEG Európai Központ, Nr. 5.

Krugman, P. (1999). The Role of Geography in Development. International Regional Science Review, 22, 142-161.

Mankiw, N. G., Romer, D., \& Weil, D. N. (1992). A Contribution to the Empirics of Economic Growth. The Quarterly Journal of Economics, MIT Press, 107(2), 407-437.

Moran, P. A. P. (1950). Notes on continuous stochastic phenomena Biometrika, 37. 17-23.

Nagyné Molnár, M. (2007). A területi egyenlőtlenségek főbb összefüggései. [Main connections of territorial inequalities.] In J. Káposzta (Ed.), Regionális gazdaságtan (pp. 166-205). Debrecen: Debreceni Egyetemi Kiadó.

Nemes Nagy, J. (1990). Területi egyenlötlenségek dimenziói. [Dimensions of territorial inequalities.] Tér és Társadalom, 4(2), 15-30.

Nemes Nagy, J. (2005). Regionális elemzési módszerek. [Regional anaysis methods.] Regionális tudományi tanulmányok 11. Budapest: ELTE Regionális Földrajzi Tanszék, MTA-ELTE Regionális Tudományi Kutatócsoport.

Pénzes, J. (2011). Északkelet-Magyarország jövedelmi térszerkezetének változásai a rendszerváltás után. [Changes in the Spatial Income Structure of North-eastern Hungary After the Change of Regime.] Területi Statisztika, 14(2), 181-193.

Quah, D. T. (1996). Empirics for economic growth and convergence. European Economic Review, 40, 1353-1375. 
Romer, P. M. (1994). The Origins of Endogenous Growth. Journal of Economic Perspectives, American Economic Association, 8(1), 3-22.

Sala-i-Martin, X. (1995). The classical approach to convergence analysis. Economics Working Papers 117, Barcelona: Universitat Pompeu Fabra, Department of Economics and Business.

Szendi, D. (2015a). Differences in the spatial patterns of selected German (NUTS3) economic factors, with special regards on GDP, unemployment and enterprises. Miskolc: MicroCad Conference Paper.

Szendi, D. (2015b). A lokális humán fejlettségi index eloszlása és területi autokorrelációja Németország és Magyarország esetében. [Distribution and spatial autocorrelation of the local HDI in Germany and Hungary.] Területi Statisztika, 55(6), 556-591.

Szendi, D. (2016). Perifériák felzárkózásának esélyei, különös tekintettel Kelet-Közép-Európa két térségére. [Convergence chances of peripheral regions, with special regards on two territories from East-Central Europe.] Miskolc: Miskolci Egyetem, Vállalkozáselmélet és gyakorlat Doktori Iskola, PhD disszertáció.

Tóth, G., \& Nagy, Z. (2013). Eltérő vagy azonos fejlődési pályák? A hazai nagyvárosok és térségek összehasonlító vizsgálata. [Different or similar development pathes? Comparative analysis of the national big cities and areas.] Területi Statisztika, 53(6), $593-612$.

UN (2015). Inequality Measurement. United Nations: Development Issues No. 2. 